\title{
BMJ Open Examining the pathways for young people with drug and alcohol dependence: a mixed-method design to examine the role of a treatment programme
}

\author{
Sally Nathan, ${ }^{1}$ Patrick Rawstorne, ${ }^{1}$ Andrew Hayen, ${ }^{1}$ Joanne Bryant, ${ }^{2}$ \\ Eileen Baldry, ${ }^{3}$ Mark Ferry, ${ }^{4}$ Megan Williams, ${ }^{5}$ Marian Shanahan, ${ }^{6}$ \\ Ranmalie Jayasinha ${ }^{1}$
}

To cite: Nathan $\mathrm{S}$,

Rawstorne $\mathrm{P}$, Hayen $\mathrm{A}$, et al. Examining the pathways for young people with drug and alcohol dependence: a mixedmethod design to examine the role of a treatment programme. BMJ Open 2016;6:e010824. doi:10.1136/bmjopen-2015010824

- Prepublication history and additional material is available. To view please visit the journal (http://dx.doi.org/ 10.1136/bmjopen-2015010824).

Received 10 December 2015 Revised 20 April 2016 Accepted 26 April 2016

CrossMark

For numbered affiliations see end of article.

Correspondence to

Dr Sally Nathan;

s.nathan@unsw.edu.au

\section{ABSTRACT}

Introduction: Young people with drug and alcohol problems are likely to have poorer health and other psychosocial outcomes than other young people. Residential treatment programmes have been shown to lead to improved health and related outcomes for young people in the short term. There is very little robust research showing longer term outcomes or benefits of such programmes. This paper describes an innovative protocol to examine the longer term outcomes and experiences of young people referred to a residential life management and treatment programme in Australia designed to address alcohol and drug issues in a holistic manner.

Methods and analysis: This is a mixed-methods study that will retrospectively and prospectively examine young people's pathways into and out of a residential life management programme. The study involves 3 components: (1) retrospective data linkage of programme data to health and criminal justice administrative data sets, (2) prospective cohort (using existing programme baseline data and a follow-up survey) and (3) qualitative in-depth interviews with a subsample of the prospective cohort. The study will compare findings among young people who are referred and (a) stay 30 days or more in the programme (including those who go on to continuing care and those who do not); (b) start, but stay fewer than 30 days in the programme; (c) are assessed, but do not start the programme.

Ethics and dissemination: Ethics approval has been sought from several ethics committees including a university ethics committee, state health departments and an Aboriginal-specific ethics committee. The results of the study will be published in peer-reviewed journals, presented at research conferences, disseminated via a report for the general public and through Facebook communications. The study will inform the field more broadly about the value of different methods in evaluating programmes and examining the pathways and trajectories of vulnerable young people.

\section{Strengths and limitations of this study}

- The proposed study directly addresses key gaps in the current research evidence evaluating residential drug and alcohol treatment programmes for young people.

- The study includes a comparison group and is the first internationally to combine multiple methods (data linkage and a prospective cohort study using a survey and in-depth interviews).

- There is potential loss to follow-up in the prospective cohort arm as the study includes a hard to reach population.

- Potential limitations of data linkage include data errors, mismatching of records and missing data, however using administrative data together with data from a prospective cohort will assist in addressing these issues.

- The advantages of using administrative data in the linkage component include the ability to obtain information on large numbers of young people spanning many years with minimised loss to follow-up and on a wide range of outcomes, including health and crime.

\section{INTRODUCTION}

There can be a range of adverse physical, psychological and social impacts of drug use at all ages. ${ }^{1}{ }^{2}$ However, research has highlighted the significant effects of alcohol and other drugs on the developing brains of young people. ${ }^{13}$ In Australia, alcohol, cannabis and tobacco are the most common currently used drugs (past 7 days) and recently used drugs (past 12 months) among young people. $^{24}$ It is estimated that $30 \%$ of young people aged 12-24 years drank alcohol at risky or high-risk levels for short-term harm and $12 \%$ for long-term harm. ${ }^{5}$ Aboriginal young people experience a disproportionate 
burden due to alcohol. ${ }^{5}$ According to the WHO, the leading cause of healthy life years lost for males aged $15-19$ years in high-income countries, such as Australia, the UK, Canada and the USA, is alcohol misuse, while substance misuse was in the top 10 for all young people aged 15-19 years. ${ }^{6}$ Among those aged $16-24$ years in Australia, 13\% reported having a substance use disorder, with alcohol being the most common drug of concern, followed by cannabis and stimulants. ${ }^{5}$ In 2012-2013, those aged 10-19 years comprised $14 \%$ of total clients seeking treatment for their own drug and/or alcohol use across Australia. ${ }^{7}$

A recent study ${ }^{8}$ of an adolescent population admitted to residential treatment in Australia from 2009 to 2014 found that meth/amphetamines were the only drug class with an upward trend in reports of drug of greatest concern (10.8-48.4\%) and current use of drug at admission (28.8-59.4\%). Additionally, $64.1 \%$ of participants reported currently using alcohol, $85.2 \%$ cannabis and $72.7 \%$ tobacco in 2014.

The impact on health of drug and alcohol misuse is reflected in hospital separations data. In 2008-2009, there were 8442 reported hospital separations for those aged 12-24 years where the main diagnosis was for mental and behavioural disorders due to drug and/or alcohol use, a rate of 218/100 000 across Australia. ${ }^{5}$ Over half of the separations were due to alcohol use $(61 \%)$, and $14 \%$ due to cannabis use. ${ }^{5}$ Amphetaminerelated hospital separations in 2011-2012 for 10-19-year olds were the highest since 1993-1994 and have steadily increased over the past 3 years. ${ }^{9}$ Cannabis-related separations among 10-19-year olds remain low, but have started to increase over the past 5 years. ${ }^{9}$

Young people with drug and alcohol problems have been reported to be at greater risk of offending. ${ }^{10}{ }^{11}$ At least two-thirds of young people in custody surveyed in Australia reported they had used illicit drugs or had been drunk at least weekly in the year prior to custody. ${ }^{12}$ Further, only 23\% reported ever receiving support to address a drug and alcohol problem despite $61 \%$ having said their alcohol use, and $45 \%$ said their drug use had caused them problems in the last year. ${ }^{12}$ Aboriginal young people are grossly over-represented in the criminal justice system in Australia, ${ }^{13}$ being 24 times more likely to be in a juvenile correctional facility compared with others, ${ }^{14}$ and being more likely to have long-term engagement with the system. ${ }^{15}{ }^{16}$ Apart from an ongoing study by Halsey, ${ }^{17}$ little is known about the pathways of those who desist from reoffending compared with those who reoffend, ${ }^{18}$ particularly in Australia. ${ }^{19}$

Some literature suggests that addressing alcohol and drug use in a holistic manner may lead to improved health and legal outcomes. ${ }^{20-23}$ Residential treatment programmes often take a holistic approach. ${ }^{24}$ Length of stay in treatment and programme completion are important to the impact and have been associated with improved outcomes, such as lower arrest rates, and positive health outcomes, for both adults and young people in the short term. ${ }^{20}{ }^{21}$ There is, however, very little robust research showing longer term outcomes or benefits of such programmes. ${ }^{25-27}$ Many programmes do not gather reliable follow-up data, report outcomes only for those who complete a programme, and have no comparison group. ${ }^{26-28}$ There have been very few high-quality outcome studies focused on residential treatment outcomes for young people internationally ${ }^{27} 29$ and none identified in Australia apart from one more than a decade ago which followed up young people to 6 months postdischarge. ${ }^{22}$ Internationally, one study found positive effects on substance use and psychological functioning in the first 12 months following intake were not maintained longer term, with no evidence of positive effects on criminal activity and general functioning in the later years. ${ }^{29}$ A further study found reductions in substance use, school absences, delinquent behaviour and hospitalisations up to 2 years post-treatment though had no comparison group. ${ }^{30}$ Recommendations are made for continuing support postdischarge as a way to prevent the erosion of short-term effects of programmes, ${ }^{29}$ but evidence is scarce. $^{31-33}$

Equally lacking is evidence on the costs and economic benefits of treatment for young people. A 2005 review on the economic costs and/or benefits of young people's substance misuse treatments found only three relevant studies. ${ }^{34}$ A subsequent systematic review of literature on interventions for young people experiencing alcohol-related harms found no economic or cost analyses of such programmes. ${ }^{35}$

This paper describes an innovative research design to examine the outcomes and experiences of young people referred to a residential life management programme in Australia, designed to address alcohol and drug issues in a holistic manner. The proposed study directly addresses key gaps in current research evidence evaluating residential treatment programmes for young people.

\section{The programme}

The Program for Adolescent Life Management (PALM) is a modified therapeutic community (TC) ${ }^{36}$ for young people with alcohol and other drug difficulties as well as underlying and associated life problems, such as family dysfunction and trauma. The TC approach aims to support young people to develop skills to manage their lives. In accordance with Australia's National Drug Strategy $^{37}$ it takes a harm minimisation approach, and does not expect complete abstinence post-treatment. Specifically, the ultimate goal of PALM is to build a positive basis for life outside the programme, including stability in accommodation, employment and positive social and family networks, and it includes a focus on psychosocial functioning using individual and group therapy, vocational education and TC mechanisms to effect change. ${ }^{25}{ }^{36}$ Residents come from varying socioeconomic backgrounds and many have a history of social and family dysfunction, early school leaving and criminal activity-between 2001 and 2005, 70\% had 
been arrested at least once in the 3 months prior to attending the programme. ${ }^{38}$ Aboriginal young people comprise $\sim 30 \%$ of PALM referrals.

In addition to PALM is the Continual Adolescent Life Management (CALM) programme. CALM is a 3-year continuing support programme offered to all clients who have participated in PALM. CALM aims to assist young people to overcome ongoing barriers they experience in life, namely alcohol and drug use, criminal activity, mental health and social exclusion. Staff provide counselling, vocational education, housing and employment assistance through face-to-face meetings, telephone and Facebook contact.

\section{METHODS AND ANALYSIS \\ Objective}

This research project will examine and analyse a range of health and social outcomes and experiences for young people who have participated in PALM compared with similar young people who have not completed such a programme, who have drug and/or alcohol issues.

\section{Aims}

1. To describe and compare the health, social and criminal justice outcomes over the short term (up to 1 year postdischarge from PALM) and the health and legal outcomes over the long term (up to 10 years postdischarge from PALM) among young people who are referred and (a) stay 30 days or more in PALM (including those who go on to continuing care and those who do not); (b) start, but stay <30 days in PALM; (c) are assessed, but do not start PALM.

2. To describe and compare economic costs associated with different outcomes and pathways among young people across the three comparison groups above.

3. To describe and compare outcomes of those young people who are referred to the programme by the criminal justice system to those referred from other sources.

4. If there are more positive outcomes for young people who attend or complete a life management programme, to describe and examine the perceptions of young people about the effective elements and strategies associated with these outcomes, including for those receiving continuing care and those who do not.

\section{Overview of study components}

Assessment and admission to PALM represents a point in time at which a young person is referred to a community-based programme to address their life problems, including their drug and alcohol use. PALM collects data on variables such as education, social and family functioning, mental health, criminal activity, and drug and alcohol use at referral. This provides a unique data set from which a mixed-methods study can retrospectively and prospectively examine these young people's pathways into and out of the programme. The study will compare key outcomes and events across the three groups (a) $-(\mathrm{c})$, examine the role of continuing care, and the economic costs associated with different outcomes and pathways.

The study involves three components:

1. Retrospective data linkage of programme data to health and criminal justice administrative data sets. The data linkage component will examine contacts with the health and justice systems prior to and postreferral for the whole data set held by PALM from 2000 to 2014 of $\sim 4000$ clients (figure 1) addressing aims 1-3.

2. A prospective cohort (using existing programme baseline data and a follow-up survey). This will include a survey at 12 months postadmission to PALM addressing aims 1-3. The survey will be completed by $\sim 400$ young people over a 2-3-year period that consent at referral.

3. Qualitative in-depth interviews with a subsample of the prospective cohort. Interviews will be undertaken with a purposefully selected ${ }^{39}$ subsample of 40 young people who have attended the programme (from the 12-month survey sample) to address aim 4.

The contribution of each component to the study aims is shown in table 1.

\section{Conceptual framework}

Psychosocial models have been used in understanding behaviour change, but remain largely focused on changes at the individual level. ${ }^{40}$ While changes at the individual level will be examined, a lifecourse perspective within a social determinants framework will inform refinement of measures and interpretation and analysis of collected data in this study. ${ }^{41} 42$ A lifecourse perspective within social science (as distinct from the epidemiological use of the term) is concerned with how one stage of life impacts another (often called transitions) and the roles of cultural and social structures in these transitions. ${ }^{42}$ In this study, we are focused on a specific aspect of the lifecourse-the transition from adolescence to adulthood. A lifecourse perspective on drug and alcohol issues suggests that an earlier onset of drug use might be associated with increased levels of drug dependence and abuse, brain injury, criminal justice involvement, and risky injection practices and sexual practices in later life. ${ }^{43}$

This lifecourse perspective and acknowledgement of social determinants is very relevant when understanding the lives and experiences of Aboriginal young people. ${ }^{44}$ In addition to poverty, ${ }^{46}$ Aboriginal young people have often experienced intergenerational disadvantage and trauma, ${ }^{45}$ 47-49 more family intervention by government agencies and care and protection orders, ${ }^{50}{ }^{51}$ as well as the regular and compounding effects of racism. ${ }^{52} 53$ This study acknowledges the impact of colonisation and history as additional determinants of health and contact with the criminal justice system among Aboriginal people. ${ }^{54-56}$ 


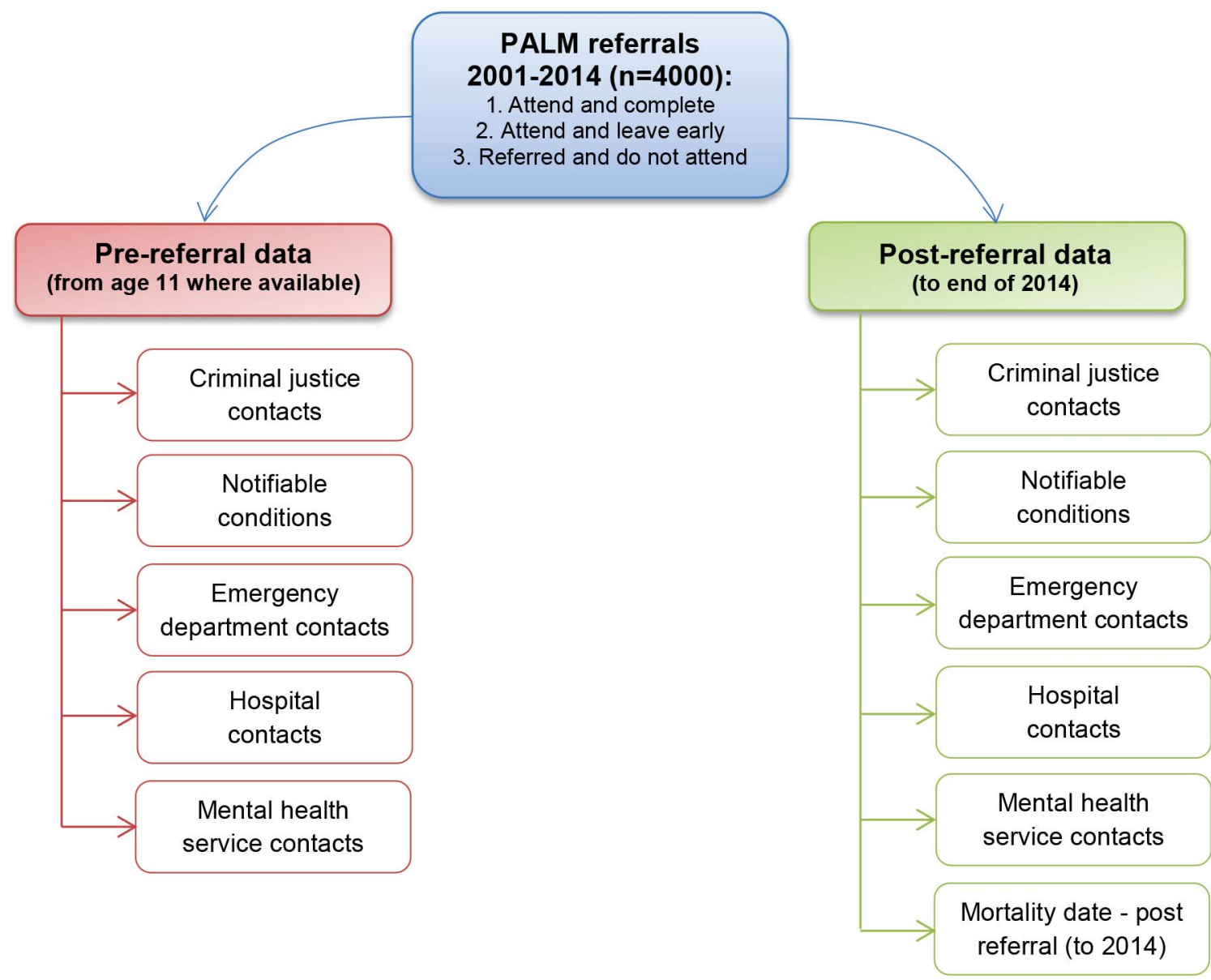

Figure 1 Retrospective data linkage component. PALM, Program for Adolescent Life Management.

Table 1 Relationship between project objectives and study components

\begin{tabular}{lll}
$\begin{array}{l}\text { Retrospective cohort: } \\
\text { data linkage }\end{array}$ & $\begin{array}{l}\text { Prospective } \\
\text { cohort: survey }\end{array}$ & $\begin{array}{l}\text { Prospective } \\
\text { cohort: interview }\end{array}$ \\
\hline $\mathrm{X}$ & $\mathrm{X}$ & \\
\hline
\end{tabular}

Aim 1: to describe and compare the health, social and criminal justice outcomes over the short term and long term among young people who are referred across the three comparison groups

Aim 2: to describe and compare economic costs associated with different outcomes and pathways among young people across the three comparison groups

Aim 3: to describe and compare outcomes of those $\mathrm{X}$ $\mathrm{x}$ young people who are referred to the programme by the criminal justice system to those referred from other sources

Aim 4: if there are more positive outcomes for young people who attend or complete a life management programme, to describe and examine the perceptions of young people about the effective elements and strategies associated with these outcomes, including for those who receive continuing care and those who do not 
These related perspectives will be integrated to examine and understand the data collected. The authors will develop an explanatory model of the factors and events characterising youth pathways, and identify the points of intervention and experiences, including aspects of PALM and CALM, which may produce more positive life trajectories.

\section{Retrospective cohort component-data linkage}

Data linkage is increasingly being used in health research to examine outcomes of programmes and the pathways of vulnerable people, including young people. ${ }^{58}$ To date, relevant studies linking administrative and programme data in the drug and alcohol field have been focused on adults ${ }^{59-63}$ and have not combined findings with a prospective cohort study. In the justice sector, linkage studies are relatively new and few have focused specifically on juveniles ${ }^{64} 65$ and often link only basic demographic correlates with outcomes. ${ }^{65}$ Nevertheless, research using linked and merged detailed lifelong administrative data, including childhood and young person data, shows the feasibility and value of data linkage to provide understanding of the complex range of factors in a young person's life in determining adult outcomes. ${ }^{66}$

\section{Data collection}

Data for the complete PALM client database (TED) from 2000 to 2014 will be linked to administrative data from a series of health and criminal government data sets from two Australian jurisdictions (figure 1).

The health system variables will include attendance at an emergency department, including date of presentation, referral source (self, police), diagnosis and outcome of treatment. The variables for patients admitted to hospital will include hospital separations (a separation is the administrative process by which a hospital records the cessation of an episode of care for a patient within the one hospital stay, eg, discharge to home, discharge to another hospital or nursing home, or death), length of stay for each visit, number of diagnosis and most common diagnosis. Mental health variables are from mental health day programmes, psychiatric outpatients and outreach services (eg, home visits) including mental health service usage such as an episode of care and duration of contact, type of service provider, such as a counsellor or youth worker number of diagnoses and most common diagnosis. Mortality will be identified from registrations of deaths, which is mandatory in Australia. Examining mortality is important as the study population group is at greater risk of self-harm, suicide and drug overdose. Notifiable diseases (including bloodborne viruses) and mortality as a result of a notifiable disease will also be included in the data set for analysis. The criminal justice data sets will contain key variables relevant to understanding offending and reoffending behaviour including police apprehensions, age at first and subsequent court appearance, offence types and penalties (table 2). See online supplementary material and figure S1 for detailed information on the data linkage process.

\section{Data analysis}

The data linkage component will enable the study team to compare healthcare utilisation (eg, hospitalisation rates), legal outcomes (such as reincarceration rates) and associated costs for across the three comparison groups. The analysis will have $>90 \%$ power to detect a difference between the 2-year reoffending rate of $65 \%$ for those who are assessed, but do not start PALM (we expect about 600 clients from 2000 to 2014) compared with a rate of $55 \%$ for those who complete at least 30 days of PALM (about 1700 clients). We will use propensity score methods to reduce confounding when conducting comparisons. ${ }^{67} \mathrm{~A}$ comparison of the 2-year reoffending rate using logistic regression will be conducted. Analyses will also be conducted using proportional hazards models to examine time to first event (eg, reincarceration, hospitalisation). In addition, count data regression methods will be used to examine the number of arrests, hospitalisations and other key events. This aspect of the study will provide data on offending and health events (and their associated costs), which occur among the study population after and prior to referral.

The analysis of costs and outcomes/events will be reported in the form of cost-consequences analysis ${ }^{68}$ drawing on findings from the data linkage and survey component (discussed further below). This form of economic analysis is appropriate for examining a range of outcomes as it accounts for different types of benefit that cannot be measured using the same units. ${ }^{68}{ }^{69} \mathrm{It}$ allows costs and benefits to be presented separately or disaggregated enabling different decision makers to focus on benefits and costs of interest to them and is particularly appropriate for public health interventions. ${ }^{68}$

\section{Prospective cohort component-survey}

The 12-month survey is an adaptation of the Ted Noffs Foundation referral survey completed at baseline and will be completed by $\sim 400$ young people over a $2-3$-year period that consent at referral (figure 2). The survey instrument was adapted drawing on the expertise of the investigators to ensure a cost-consequence analysis could be conducted, and key demographics and important background details included that may impact on treatment effects and pathways.

\section{Data collection}

Young people who have consented to participate will be followed up by phone, mobile messaging and a study Facebook page to arrange a time to complete a phone survey at 12 months postreferral to PALM. We expect at least $75 \%$ of those who consent at baseline to participate at 12 months postreferral based on previous research with young people. ${ }^{20} 22$ Reimbursement for participation and multiple methods for contacts will be required at 


\begin{tabular}{|c|c|c|c|c|c|c|}
\hline Health data set & Data description & Data provider & Data type & $\begin{array}{l}\text { Geographical } \\
\text { coverage }\end{array}$ & $\begin{array}{l}\text { Available } \\
\text { from }\end{array}$ & Key variables \\
\hline $\begin{array}{l}\text { Admitted Patients } \\
\text { Data Collection }\end{array}$ & $\begin{array}{l}\text { NSW-all admitted patient } \\
\text { services provided by public and } \\
\text { private hospitals and day } \\
\text { procedure centres } \\
\text { ACT-inpatient separations from } \\
\text { all public and private hospitals }\end{array}$ & $\begin{array}{l}\text { NSW Health } \\
\text { ACT Health }\end{array}$ & $\begin{array}{l}\text { Administrative } \\
\text { (mandatory) }\end{array}$ & $\begin{array}{l}\text { NSW } \\
\text { ACT }\end{array}$ & $\begin{array}{l}2001 \\
2004\end{array}$ & $\begin{array}{l}\text { Date of admission } \\
\text { Date of separation } \\
\text { Length of stay } \\
\text { Primary and additional diagnoses } \\
\text { Admitted to and days in psychiatry ward } \\
\text { Separation mode } \\
\text { Demographics (age, sex, SLA of residence) }\end{array}$ \\
\hline $\begin{array}{l}\text { Death } \\
\text { registrations } \\
\text { Cause of Death } \\
\text { Unit Record File }\end{array}$ & $\begin{array}{l}\text { Mortality information for deaths } \\
\text { occurring in NSW and ACT }\end{array}$ & $\begin{array}{l}\text { NSW Registry } \\
\text { of Births, } \\
\text { Deaths and } \\
\text { Marriages } \\
\text { ACT Registry } \\
\text { of Births, } \\
\text { Deaths and } \\
\text { Marriages }\end{array}$ & $\begin{array}{l}\text { Registry } \\
\text { (mandatory) }\end{array}$ & $\begin{array}{l}\text { NSW } \\
\text { ACT }\end{array}$ & $\begin{array}{l}1985 \\
1997\end{array}$ & $\begin{array}{l}\text { Date of birth } \\
\text { Date of death } \\
\text { Age at death } \\
\text { Year of death registration } \\
\text { Cause of death }\end{array}$ \\
\hline $\begin{array}{l}\text { Emergency } \\
\text { Department Data } \\
\text { Collection }\end{array}$ & $\begin{array}{l}\text { Provides information about patient } \\
\text { presentations to the emergency } \\
\text { departments of public hospitals in } \\
\text { NSW and ACT }\end{array}$ & $\begin{array}{l}\text { NSW Health } \\
\text { ACT Health }\end{array}$ & $\begin{array}{l}\text { Administrative } \\
\text { (mandatory) }\end{array}$ & $\begin{array}{l}\text { NSW } \\
\text { ACT }\end{array}$ & $\begin{array}{l}2005 \\
2004\end{array}$ & $\begin{array}{l}\text { Arrival and triage date } \\
\text { Doctor seen date } \\
\text { Mode of arrival and referral source } \\
\text { Diagnosis Mode of separation } \\
\text { Departure date } \\
\text { Demographics (age, sex, SLA) }\end{array}$ \\
\hline $\begin{array}{l}\text { Mental Health } \\
\text { Ambulatory Data } \\
\text { Collection }\end{array}$ & $\begin{array}{l}\text { Includes assessment, treatment, } \\
\text { rehabilitation or care of } \\
\text { non-admitted patients. It may } \\
\text { include mental health day } \\
\text { programmes, psychiatric } \\
\text { outpatients and outreach services } \\
\text { (eg, home visits). }\end{array}$ & NSW Health & Administrative & NSW & 2001 & $\begin{array}{l}\text { Activity type and duration } \\
\text { Activity start date } \\
\text { Group session identifier } \\
\text { Mental health additional diagnosis } \\
\text { Mental health provider role and type } \\
\text { Demographics (age, area of usual residence, country } \\
\text { of birth) }\end{array}$ \\
\hline $\begin{array}{l}\text { Notifiable } \\
\text { Conditions/ } \\
\text { Diseases }\end{array}$ & $\begin{array}{l}\text { Diagnoses of certain infectious } \\
\text { diseases and adverse events } \\
\text { following immunisation. Notified by } \\
\text { laboratories, hospitals, medical } \\
\text { practitioners, schools and child } \\
\text { care centres }\end{array}$ & $\begin{array}{l}\text { NSW Health } \\
\text { ACT Health }\end{array}$ & $\begin{array}{l}\text { Administrative } \\
\text { (mandatory) }\end{array}$ & $\begin{array}{l}\text { NSW } \\
\text { ACT }\end{array}$ & $\begin{array}{l}1993 \\
2000\end{array}$ & $\begin{array}{l}\text { Disease name/condition notified } \\
\text { Diagnosis method } \\
\text { Recorded date } \\
\text { Laboratory confirmed } \\
\text { Demographics (age, sex, SLA) }\end{array}$ \\
\hline $\begin{array}{l}\text { Criminal justice } \\
\text { data sets }\end{array}$ & Data description & Data provider & Data type & $\begin{array}{l}\text { Geographical } \\
\text { coverage }\end{array}$ & $\begin{array}{l}\text { Available } \\
\text { from }\end{array}$ & Key variables \\
\hline PROMIS & $\begin{array}{l}\text { Central recording system for all } \\
\text { crime, incidents and offences } \\
\text { committed in the ACT }\end{array}$ & ACT Police & Administrative & ACT & 1998 & $\begin{array}{l}\text { Date arrested } \\
\text { Date of offence for which arrested } \\
\text { Offence committed-Australian Standard Offence } \\
\text { Classification } \\
\text { Method used to clear an offence or charge }{ }^{\mathrm{ii}} \text { and date } \\
\text { cleared }\end{array}$ \\
\hline
\end{tabular}

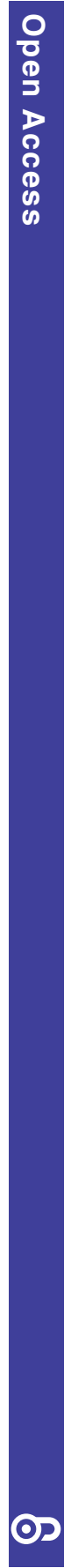

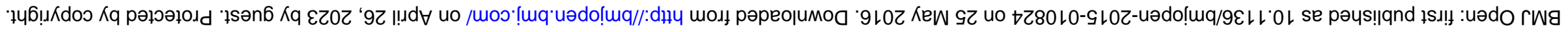




\section{Health data set \\ Data description}

Contains information on each

person who has been convicted of

a criminal offence in NSW since

1994 and is used by the Bureau of

Crime Statistics and Research to

determine the proportion of

offenders who have been

re-convicted for a further offence

Geographical Available

coverage

from

\section{Key variables}

Date released following apprehension

Family violence related

Court appearances

Principal offence-Australian Standard Offence

Classification

Date offence occurred

Date accused was arrested/charged for offence

Plea and outcome of the charge

Drug associated with offence

Year and jurisdiction case was finalised

Type and duration or value of penalty

Duration of total term for prison sentence

Custody - those in custody (date of reception, type of

custody, sentence type, date of discharge, discharged type)

\begin{tabular}{|c|c|c|c|c|c|c|}
\hline $\begin{array}{l}\text { Reference data } \\
\text { set }\end{array}$ & Data description & Data provider & Data type & $\begin{array}{l}\text { Geographical } \\
\text { coverage }\end{array}$ & $\begin{array}{l}\text { Available } \\
\text { from }\end{array}$ & Key variables \\
\hline TED Database & $\begin{array}{l}\text { TED is the Ted Noffs Foundation } \\
\text { Client Information System for } \\
\text { young people referred for } \\
\text { residential drug treatment in NSW } \\
\text { and the ACT since } 2001 \text {. Includes } \\
\text { all variables in a pretreatment } \\
\text { referral questionnaire administered } \\
\text { by staff over the phone or in } \\
\text { person }\end{array}$ & $\begin{array}{l}\text { Ted Noffs } \\
\text { Foundation }\end{array}$ & Administrative & $\begin{array}{l}\text { NSW } \\
\text { ACT }\end{array}$ & 2000 & $\begin{array}{l}\text { Admission to PALM (referral source, date of } \\
\text { admission, date of discharge, reason for departure) } \\
\text { Demographics (age, Indigenous status, education, } \\
\text { occupation, housing) } \\
\text { Substance use (age first use, current use, route of } \\
\text { administration) } \\
\text { Severity of Dependence Scale (table 3) } \\
\text { Occasions of Drug Use Scale (table 3) } \\
\text { Blood Borne Virus Exposure Risk Scale (table 3) } \\
\text { Treatment history and motivation to attend treatment } \\
\text { Psychological Wellbeing Scale (table 3) } \\
\text { Suicide and self-harm attempts (ever attempted, } \\
\text { attempted } 3 \text { months) } \\
\text { Social Functioning Scale (table 3) } \\
\text { Family Assessment Device (General Functioning } \\
\text { Scale; table 3) } \\
\text { Past criminal activity (times arrested } 3 \text { months prior to } \\
\text { screening, times in custody, type and number of } \\
\text { crimes committed, under the influence of alcohol or } \\
\text { any other drugs during any offences) }\end{array}$ \\
\hline
\end{tabular}

A separation is the administrative process by which a hospital records the cessation of an episode of care for a patient within the one hospital stay e.g. discharge to home, discharge to another hospital or nursing home, or death

ii"Method could include caution, summons, charge withdrawn, unfounded, court, attendance notice, charge before the court, diversionary conference, simple Cannabis Offence Notice.

ACT, Australian Capital Territory; BOCSAR, Bureau of Crime Statistics and Research; NSW, New South Wales; PALM, Program for Adolescent Life Management; PROMIS, Police Real Time

Online Management Information System; SLA, Statistical Local Area. 


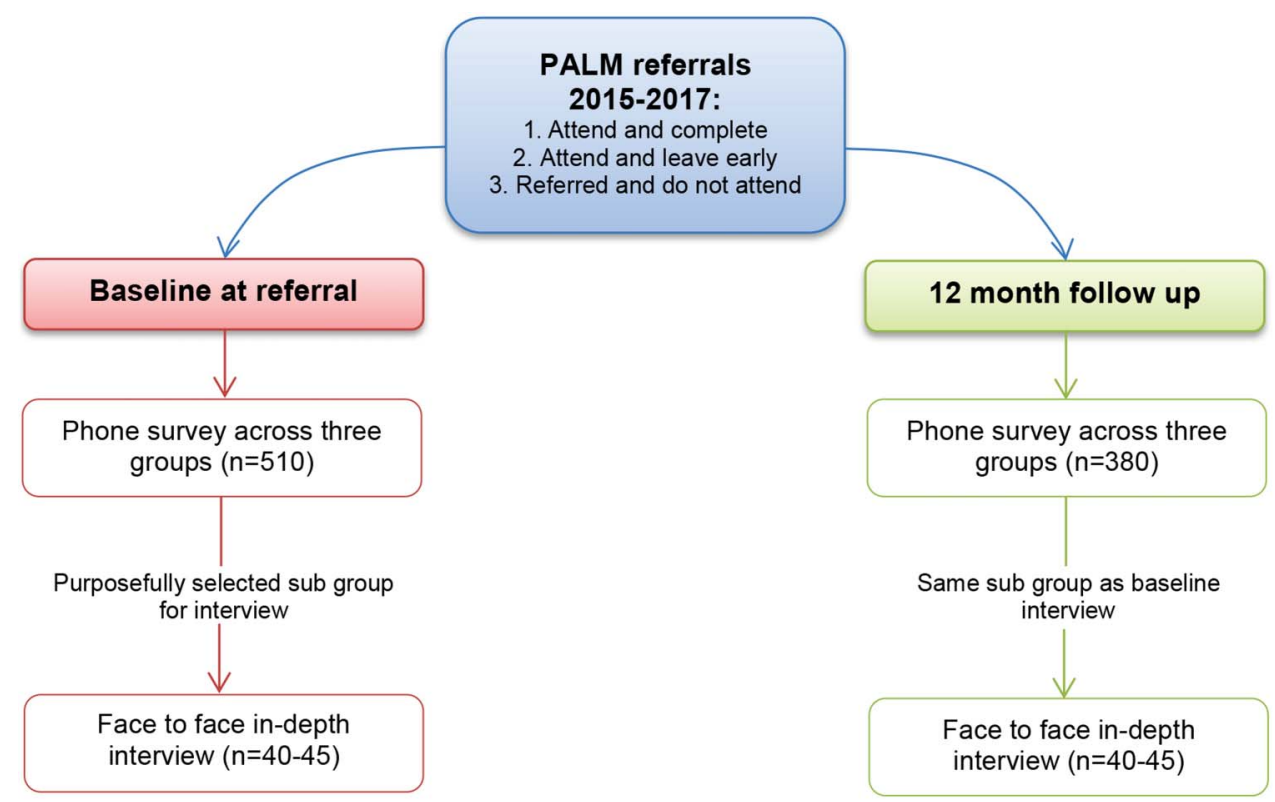

Figure 2 Prospective cohort survey and interview components. PALM, Program for Adolescent Life Management.

consent to achieve the projected response rates. Facebook and mobile phone messaging will be important means to follow-up young people. Facebook is currently used by CALM with most clients each year staying more than 30 days in PALM becoming friends of their Facebook site. Facebook was also identified in a pilot study earlier this year as a preferred method of contact among former clients. Outcomes and experiences of the

Table 3 Instruments included in the survey

\begin{tabular}{|c|c|c|}
\hline Instrument /items & Constructs measured & Psychometric testing \\
\hline $\begin{array}{l}\text { Severity of Dependence Scale } \\
(\text { SDS })^{70} \\
\text { GAIN Short Screener } \\
\text { (GAIN-SS) (Psychological } \\
\text { Functioning Scale) }{ }^{71}\end{array}$ & $\begin{array}{l}\text { Degree of psychological dependence on } \\
\text { different illicit drugs } \\
\text { Psychological functioning: background; } \\
\text { substance use; physical health; risk } \\
\text { behaviours; mental health; and environment, } \\
\text { legal and vocational factors }\end{array}$ & $\begin{array}{l}\text { Published psychometric data available } e^{70} \\
\text { Australian comparative data available } \\
\text { Published psychometric data available } \\
\text { Australian comparative data available } \\
\text { A6 }\end{array}$ \\
\hline $\begin{array}{l}\text { The Opiate Treatment Index } \\
\text { (Social Functioning Scale } \\
(\text { SFS }))^{72} 73\end{array}$ & $\begin{array}{l}\text { Social functioning: drug use; HIV risk-taking } \\
\text { behaviour, social functioning criminality, } \\
\text { health and psychological adjustment }\end{array}$ & $\begin{array}{l}\text { Published psychometric data available }{ }^{73} \\
\text { Australian comparative data available }\end{array}$ \\
\hline $\begin{array}{l}\text { Blood-Borne Virus Exposure } \\
\text { Risk scale (BBVER) }\end{array}$ & $\begin{array}{l}\text { Injecting drug behaviour: item of injection } \\
\text { equipment used }\end{array}$ & $\begin{array}{l}\text { Published psychometric data available from } \\
\text { Australia }^{66}\end{array}$ \\
\hline $\begin{array}{l}\text { Occasions of Drug Use Index } \\
\text { (ODUI) and polydrug use }\end{array}$ & $\begin{array}{l}\text { Number of days in the last month that they } \\
\text { used the following: alcohol, heroin and other } \\
\text { illicit opioids, cannabis, cocaine, } \\
\text { amphetamines, tranquilisers and tobacco }\end{array}$ & $\begin{array}{l}\text { Published psychometric data available from } \\
\text { Australia }^{76}\end{array}$ \\
\hline $\begin{array}{l}\text { Family Assessment Device } \\
\text { (FAD)-General Functioning } \\
\text { Scale }^{79} 80\end{array}$ & $\begin{array}{l}\text { Structural, organisational and transactional } \\
\text { characteristics of families }\end{array}$ & Published psychometric data available ${ }^{79}$ \\
\hline EQ-5D-5L Quality of Life Scale & $\begin{array}{l}\text { Measures quality of life using } 5 \text { levels } \\
\text { across } 5 \text { dimensions: mobility, self-care, } \\
\text { usual activities, pain/discomfort, anxiety/ } \\
\text { depression }\end{array}$ & Published psychometric data available ${ }^{74}$ \\
\hline $\begin{array}{l}\text { Australian and New Zealand } \\
\text { Standard Offence Classification } \\
\text { (ANZSOC) } \text { codes }^{75}\end{array}$ & $\begin{array}{l}\text { Number of arrests, type of offence } \\
\text { committed and outcomes of arrests }\end{array}$ & $\begin{array}{l}\text { The items measure offence-related events } \\
\text { not psychological constructs }\end{array}$ \\
\hline $\begin{array}{l}\text { Health service utilisation } \\
\text { questionnaire }\end{array}$ & $\begin{array}{l}\text { Type and number of health services } \\
\text { accessed }\end{array}$ & $\begin{array}{l}\text { The items measure health service events } \\
\text { not psychological constructs. The } \\
\text { instrument has been used previously in } \\
\text { Australian studies. }{ }^{81-83}\end{array}$ \\
\hline
\end{tabular}


young people to be collected will include drug and alcohol use, physical and mental health, social and family functioning using validated instruments currently used by the programme at assessment or baseline compared across the three groups. These include items from the Severity of Dependence Scale $(\text { SDS })^{70}$ and Psychological and Social Functioning Scales ${ }^{71-73}$ as well as items related to treatment for drug and/or alcohol and related issues. To support the economic analyses, the EQ-5D-5L quality of life scale ${ }^{74}$ and items related to health services utilisation and criminal offences, based on Australian Standard Offence Classification (ASOC) codes ${ }^{75}$ will be included (table 3 ).

\section{Data analysis}

In the 12-month survey component, there will be 165 clients who stay 30 days or more in PALM; another 165 who start, but stay <30 days in PALM; and 180 who are assessed, but do not start PALM. Based on previous research experience at the programme ${ }^{38}$ and related studies ${ }^{20}{ }^{22}$ the team will be able to recruit and follow-up about $75 \%$ of these clients for 12 months, which will give 124, 124 and 135 clients in the three groups, respectively. This will enable detection of a difference at 12 months of 0.4 SDs between either of the groups that attend PALM versus the group that does not attend with $\alpha$ of 0.05 and power of $90 \%$ for either of two primary outcome measures, the Psychological Functioning and the Severity of Dependence scales. Previous research has indicated that much larger differences are likely to be observed. ${ }^{84}$ The analysis will compare Psychological Functioning and Severity of Dependence scores at 12 months across the three groups using multiple linear regression after adjusting for potential confounders such as previous criminal history, Psychological Functioning and Severity of Dependence scores at referral, gender and age. Days in PALM will be used as a continuous variable to examine 'dose-response'. Analysis using propensity score methods to compare across the groups will also be used; propensity scoring is a statistical technique which reduces bias from confounders. ${ }^{67}$ In addition, assessment and interview data collected at 0 months across the three groups will assist in understanding differences at baseline between the groups and inform statistical analysis and interpretation.

\section{Prospective cohort component-in-depth interviews}

Qualitative interviews will be undertaken to provide data and insights about the individual, structural and social features that shape young people's histories, and subsequent experiences in PALM and CALM including their life trajectories up to 12 months postreferral. The in-depth interview component will only include young people who attend the programme including those that stay less and more than 30 days (figure 2). This component is to address aim 4 which is focused on describing and examining effective elements and strategies associated with positive outcomes for young people who attend or complete a life management programme, including for those receiving continuing care.

\section{Data collection}

A purposeful sample ${ }^{39}$ of 40 young people who attend PALM will be invited to participate in qualitative in-depth interviews with sampling aiming to include a diversity of participants, for example, males, females, programme completers and non-completers, and Aboriginal young people to build a data set that informs and develops theory. ${ }^{85}$ These young people interviewed twice will provide substantial data for analysis. ${ }^{86}$ Baseline interviews will be undertaken at intake in the first few weeks in PALM, helping to establish rapport and trust and gain informed consent, and again at 12 months face-to-face wherever possible or by phone at the time or soon after the follow-up survey. The interviews will be semistructured, exploring the young people's perspectives of their own drug and alcohol use; the strength of their social ties with family, peers and significant others; their expectations of and experiences with services like PALM; and their experiences with crime. The approach to these interviews and specific question types are under review and will be developed with young people who have attended the programme. The in-depth interview is likely to be adapted over time based on interviewer experiences. $^{87}$

\section{Data analysis}

Analysis of the interview data will include initial inductive thematic analysis ${ }^{85}$ using NVIVO to assist with data management and to link survey and interview respondent findings using attribute features of NVIVO enabling triangulation. ${ }^{86} 88$ This will be complemented by more intensive narrative analysis ${ }^{89}$ of a subgroup of interviews selected to reflect diversity of experiences.

\section{Ethics and dissemination}

Ethics approval has been sought from several ethics committees including a university Human Research Ethics Committee (HREC), state health departments for access to administrative data for linkage and an Aboriginal-specific ethics committee.

\section{Ethical considerations}

This study involves the recruitment of young people, many of whom have experienced significant disadvantage and marginalisation during their lives. As such, there are a number of ethical considerations related to ensuring safety and protection of these young people throughout the study.

\section{Verbal consent for the survey and interview}

Some young people referred to the PALM programme undertake the initial assessment over the phone as they are in a rural area or juvenile detention at the time of referral and many have low literacy levels. Verbal consent, using a carefully scripted process is therefore 
being used instead of written consent. Ted Noffs Foundation staff or counsellors will use this verbal consent process to obtain informed consent from participants after they have completed their entry assessment for PALM. Verbal consent will be reobtained at the time of the survey at 12 months and prior to each in-depth interview.

\section{Consent for those aged 16 years and under}

Approximately $20 \%$ of potential participants will be aged 16 years and under. For these participants' parents or carers will be approached to also provide consent. These young people will be asked whether they wish their parents or carer to be informed of their intention to participate. Contacting family members is sometimes not appropriate due to the history of family problems. If the young person wishes to participate and is under 16 years of age and does not wish their parent or carer to be contacted, then a process adapted from the Gillick Competence test and the Fraser Guidelines ${ }^{90}$ used for medical procedures will be used to assess a young person's competence to give consent without parent involvement. PALM staff assessing competency to consent will be trained psychologists, social workers, counsellors or an alcohol and other drug worker.

\section{Aboriginal participants}

As the sample comprises a significant proportion of Aboriginal clients (over 30\%), the research design reflects values of Aboriginal research, detailed in the Australian National Health and Medical Research Council (NHMRC) guidelines. $^{91}{ }^{92}$ Aboriginal Community Controlled Health Organisations (ACCHOs) are seen as partners in the research, and Aboriginal researchers (one of whom is an investigator on the study) are involved in the design and conduct of this aspect of the study, in particular the interview component. These organisations and individuals are members of an Aboriginal Advisory Committee (AAC; see below).

\section{Waiver of consent for data linkage}

Ethics approval for a waiver of consent is being sought for the data linkage component. Consent for the retrospective cohort would be very difficult logistically and also without infringing the privacy of past clients whose current partner/family/significant other may be unaware of their previous history of drug and alcohol issues. The privacy risks of consenting all past clients significantly outweigh the privacy risks of not reconsenting, which we believe are negligible with a sample of 4000 past clients over a 14-year time span with de-identification.

\section{Data linkage process}

The process of linkage is designed to ensure that the staff performing the linkage do not have access to the administrative information about the individuals. Data custodians will only have access to data within their data collections. The research team will receive data that contains no identifying variables (such as name and address).

\section{Dissemination}

Study findings will be disseminated through publications in openaccess journals, presentation of results in the third year of the study at conferences, and a report for the general public and key stakeholders of the final results, including a media and stakeholder launch of the report to increase exposure. Results will be communicated to young people via the Ted Noffs Facebook page for their continuing care programme.

\section{Governance}

This study has implications for a range of stakeholders including study participants, the Ted Noffs Foundation, data custodians in the linkage component, and Aboriginal people and their communities. A number of governance structures are being established to enable these stakeholders to have input throughout the study including the dissemination of findings.

A Youth Advisory Council (YAC) will be convened to support the study comprised of $\sim 8-10$ young people post-PALM who will meet face-to-face every 3-6 months with sitting fees and reimbursement of expenses. This group will include two Aboriginal members. The young people will be involved in a range of aspects including input to the interview schedule and processes and dissemination of findings to young people. Training will be provided to members to support their engagement, including training to understand research methods.

An AAC has been convened including representatives from three ACCHOs, two Aboriginal researchers with experience working within the corrective services context (including author MW) and two Aboriginal young people. This AAC facilitates inclusion of the worldviews of Aboriginal people in the study, to ensure data is collected in a relevant way and about meaningful issues. The AAC will have an instrumental role in reflecting on data gathered for its meaning to Aboriginal populations of young people particularly in the context of contemporary culture, history and the socioeconomic disadvantage colonised Indigenous peoples often experience. It will also provide leadership to disseminate findings in ways that do not further disadvantage or stigmatise Aboriginal people, seeking to promote understanding of Aboriginal peoples' experiences, cultures and aspirations.

\section{DISCUSSION}

This study is innovative in its approach by combining retrospective data linkage and prospective cohort components with current clients, who have drug and alcohol issues referred to a residential community life management programme with a continuing support programme 
arm. The findings will be used to advance fundamental knowledge in the fields of public health and criminology related to vulnerable and at-risk young people and the strategies and mechanisms related to improved outcomes. Specifically, it will provide critical new knowledge and understanding of how young people with drug and alcohol issues fare in the longer term and the contribution of a life management programme to their pathways and trajectories informing policy and service design relating to treatment and desistance more broadly.

The study will be the first among juvenile offenders linking programme data to justice and health administrative data sets which goes beyond basic demographic correlates to include rich demographic and a range of psychosocial measures, including drug and alcohol use collected at referral for more than a decade. The study will also be the first follow-up study of such a programme in Australia in many years and importantly will include a comparison group for the data linkage and survey components comprised of those who are assessed, but do not attend. Only one study with follow-up to 6 months postdischarge has been identified prior to this time in Australia. ${ }^{22}$ The study will also trial the use of social media as a tool for recruitment, improving response rates and communicating findings with the study population.

The integrated findings from across the diverse data sets will underpin the development of new models and theories about the factors that influence transition among these young people into adulthood. This will include a focus on the concepts of turning points and life events, ${ }^{42}$ as well as the 'desistance process' model to understand how and why people stop offending. ${ }^{93}$ Importantly, research governance will involve Aboriginal people and Aboriginal Community-Controlled Organisations in an ongoing partnership structure. The governance mechanisms will also involve young people from the participating community in key advisory and engagement processes for the first time in this field of research and will examine the mechanisms and value of their involvement.

\author{
Author affiliations \\ ${ }^{1}$ Faculty of Medicine, School of Public Health and Community Medicine, \\ UNSW Australia, Sydney, New South Wales, Australia \\ ${ }^{2}$ Faculty of Arts and Social Sciences, Centre for Social Research in Health, \\ UNSW Australia, Sydney, New South Wales, Australia \\ ${ }^{3}$ Faculty of Arts and Social Sciences, School of Social Sciences, UNSW \\ Australia, Sydney, New South Wales, Australia \\ ${ }^{4}$ Ted Noffs Foundation, Randwick, New South Wales, Australia \\ ${ }^{5}$ Centre for Health Research, Western Sydney University, Sydney, New South \\ Wales, Australia \\ ${ }^{6}$ Faculty of Medicine, National Drug and Alcohol Research Centre, UNSW \\ Australia, Sydney, New South Wales, Australia
}

Acknowledgements The Aboriginal Advisory Committee (AAC) comprised of: Representatives from three Aboriginal Community Controlled Organisations, Mr Tony Hunter from Marrin Weejali Aboriginal Corporation, Mr Dale Huddleston from Gugan Gulwan Youth Aboriginal Corporation and Ms Bonny Briggs from the Aboriginal Health and Medical Research Council. Two
Aboriginal researchers with experience working within the corrective or drug and alcohol treatment services context with Aboriginal clients including $\mathrm{Mr}$ Michael Doyle and author MW. Two Aboriginal young people who have been clients of the PALM programme. An Aboriginal staff member from Ted Noffs Foundation, Mr Leo Wright. A representative of Ted Noffs Foundation as an organisation, Mr Kieran Palmer.

Contributors SN led the design of the study with input from all of the authors and drafted the manuscript. All authors subsequently have provided comment and edited the manuscript. PR developed the survey instrument with input from SN, RJ, MW, MS and AH. SN, AH, EB and RJ have further developed the data linkage component as reflected in this manuscript. MS drafted the sections specifically focused on the economic cost and benefits component. $\mathrm{SN}, \mathrm{JB}, \mathrm{MW}$ and RJ are leading the interview component. MF contributed to the manuscript as above and in providing specific details about the PALM and CALM programmes and their baseline data collections which provides the basis for the follow-up survey. The AAC provided input to the approach taken in the interviews with Aboriginal participants. All authors have reviewed and approved the final manuscript.

Funding This research is supported under Australian Research Council's Linkage Projects funding scheme (project number LP140100429) and the Ted Noffs Foundation.

Competing interests Author MF is an employee of the partner organisation and sponsor, the Ted Noffs Foundation, which operates the PALM and CALM programmes. Ted Noffs Foundation has been working with the UNSW team for 6 years and is a signatory to the Australian Research Council Funding Contract. They are committed to acting on the findings, both positive and negative, about their programmes.

Ethics approval The UNSW Human Research Ethics Committee and Aboriginal Health and Medical Research Council Ethics Committee have approved the prospective component of this study. Ethics applications to State-level ethics committees for the retrospective component have been approved subject to Aboriginal Health and Medical Research Council Ethics which is currently under review and also final approval by ACT data custodians.

Provenance and peer review Not commissioned; externally peer reviewed.

Open Access This is an Open Access article distributed in accordance with the Creative Commons Attribution Non Commercial (CC BY-NC 4.0) license, which permits others to distribute, remix, adapt, build upon this work noncommercially, and license their derivative works on different terms, provided the original work is properly cited and the use is non-commercial. See: http:// creativecommons.org/licenses/by-nc/4.0/

\section{REFERENCES}

1. Ministerial Council on Drug Strategy (MCDS). Ministerial Council on Drug Strategy, National Drug Strategy 2010-2015: a framework for action on alcohol, tobacco and other drugs. Canberra: Commonwealth of Australia, 2011.

2. Australian Institute of Health and Welfare (AlHW). National Drug Strategy Household Survey detailed report 2013. Drug statistics series no. 28. Cat. no. PHE 183. Canberra: Australian Institute of Health and Welfare, 2014.

3. Degenhardt L, Roxburgh A, Black E, et al. The epidemiology of methamphetamine use and harm in Australia. Drug Alcohol Rev 2008;27:243-52.

4. White V, Bariola E. Australian secondary school students' use of tobacco, alcohol, and over-the-counter and illicit substances in 2011. Victoria: Centre for Behavioural Research in Cancer, The Cancer Council, 2012.

5. Australian Institute of Health and Welfare (AlHW). Young Australians: their health and wellbeing 2011. Cat. no. PHE 140 Canberra: Australian Institute of Health and Welfare, 2011.

6. World Health Organization. Health for the world's adolescents: A second change in the second decade, Geneva: World Health Organization, 2014.

7. Australian Institute of Health and Welfare (AlHW). Alcohol and other drug treatment services in Australia 2012-13. Drug treatment series no. 24. Cat. no. HSE 150. Canberra: Australian Institute of Health and Welfare, 2014. 
8. Nathan S, Bethmont A, Rawstorne PR, et al. Trends in drug use among adolescents admitted to residential treatment in Australia Med J Aust 2016;204:149-50.

9. Roxburgh A, Burns L. Drug-related hospital stays in Australia, 19932012. Sydney: National Drug and Alcohol Research Centre, UNSW Australia, 2013

10. Van Der Put CE, Deković M, Stams GJ, et al. Changes in risk factors during adolescence: implications for risk assessment. Crim Justice Behav 2011;38:248-62.

11. Van der Put CE, Stams GJ, Hoeve M, et al. Changes in the relative importance of dynamic risk factors for recidivism during adolescence. Int J Offender Ther Comp Criminol 2012;56:296-316.

12. Indig D, Vecchiato C, Haysom L, et al. 2009 NSW young people in custody health survey: full report. Sydney: Justice Health and Juvenile Justice, 2011.

13. Cunneen C, White R. Juvenile justice: youth and crime in Australia. 4th edn. Melbourne: Oxford University Press, 2011.

14. Richards K, Lyneham M. Monitoring reports 05: juveniles in detention in Australia, 1981-2008. Canberra: AIC, 2010.

15. Crime and Misconduct Commission. Restoring order: crime prevention, policing and local justice in Queensland's Indigenous communities. Brisbane: CMC, 2009.

16. Livingstone $\mathrm{M}$, Stewart $\mathrm{A}$, Allard $\mathrm{T}$, et al. Understanding juvenile offending trajectories. Aust N Z J Criminol 2008;41:345-63.

17. Halsey MJ. Imprisonment and prisoner re-entry in Australia. Dialectical Anthropol 2010;34:545-54.

18. Johnson MC, Menard S. A longitudinal study of delinquency abstention: differences between life-course abstainers and offenders from adolescence into adulthood. Youth Violence Juvenile Justice 2012;10:278-91.

19. Chen $\mathrm{S}$, Matruglio $\mathrm{T}$, Weatherburn $\mathrm{D}$, et al. The transition from juvenile to adult criminal careers. Crime and Justice Bulletin, Contemporary Issues in Crime and Justice 2005;86:1-12.

20. Galaif ER, Hser Y-I, Grella CE, et al. Prospective risk factors and treatment outcomes among adolescents in DATOS-A. J Adolesc Res 2001;16:661-78.

21. Orlando M, Chan KS, Morral AR. Retention of court-referred youths in residential treatment programs: client characteristics and treatment process effects. Am J Drug Alcohol Abuse 2003;29:337-57.

22. Spooner C, Mattick RP, Noffs W. Outcomes of a comprehensive treatment program for adolescents with a substance-use disorder. J Subst Abuse Treat 2001:20:205-13.

23. Liddle HA, Dakof GA, Henderson C, et al. Implementation outcomes of multidimensional family therapy-detention to community: a reintegration program for drug-using juvenile detainees. Int $J$ Offender Ther Comp Criminol 2011;55:587-604.

24. Dye MH, Ducharme LJ, Johnson JA, et al. Modified therapeutic communities and adherence to traditional elements. J Psychoactive Drugs 2009;41:275-83.

25. Foster M, Nathan S, Ferry M. The experience of drug-dependent adolescents in a therapeutic community. Drug Alcohol Rev 2010;29:531-9.

26. Muck R, Zempolich KA, Titus JC, et al. An overview of the effectiveness of adolescent substance abuse treatment models. Youth Soc 2001;33:143-68.

27. Tripodi SJ. A comprehensive review: methodological rigor of studies on residential treatment centers for substance-abusing adolescents. J Evid Based Soc Work 2009;6:288-99.

28. Williams RJ, Chang SY. A comprehensive and comparative review of adolescent substance abuse treatment outcome. Clin Psychol 2000;7:138-66.

29. Edelen MO, Slaughter ME, McCaffrey DF, et al. Long-term effect of community-based treatment: evidence from the adolescent outcomes project. Drug Alcohol Depend 2010;107:62-8.

30. Mills L, Pepler D, Cribbie RA. Effectiveness of residential treatment for substance abusing youth: benefits of the pine river institute program. Residential Treat Children Youth 2013;30:202-26.

31. Winters KC, Stinchfield R, Latimer WW, et al. Long-term outcome of substance-dependent youth following 12-step treatment. J Subst Abuse Treat 2007;33:61-9.

32. Godley MD, Godley SH, Dennis ML, et al. The effect of assertive continuing care on continuing care linkage, adherence and abstinence following residential treatment for adolescents with substance use disorders. Addiction 2007;102:81-93.

33. Burleson JA, Kaminer $\mathrm{Y}$, Burke $\mathrm{RH}$. Twelve-month follow-up of aftercare for adolescents with alcohol use disorders. J Subst Abuse Treat 2012:42:78-86.

34. Zavala SK, French MT, Henderson CE, et al. Guidelines and challenges for estimating the economic costs and benefits of adolescent substance abuse treatments. J Subst Abuse Treat 2005;29:191-205.
35. Calabria B, Shakeshaft AP, Harvard A. A systematic and methodological review of interventions for young people experiencing alcohol-related harm. Addiction 2011;106:1406-18.

36. De Leon G. The therapeutic community: theory, model, and method. New York: Springer Publishing Company, 2000.

37. Ministerial Council on Drug Strategy. National Drug Strategy 20102015: a framework for action on alcohol, tobacco and other drugs. Canberra: Commonwealth of Australia, 2011.

38. Arcuri A, Howard J. PALM StatsPack 2001-2005. Sydney: Ted Noffs Foundation, 2006.

39. Patton M. Qualitative research and evaluation methods. 3rd edn. Thousand Oaks: Sage Publications, 2002.

40. Elder JP, Lytle L, Sallis JF, et al. A description of the socialecological framework used in the trial of activity for adolescent girls (TAAG). Health Educ Res 2007;22:155-65.

41. Kelleher $\mathrm{H}$. Health promotion principles. In: Kelleher $\mathrm{H}$, MacDougal $\mathrm{C}$, Murphy B, eds. Understanding health promotion. Melbourne: Oxford University Press, 2007:14-28.

42. Liamputtong P, Fanany R, Verrinder G, eds. Health, illness and well-being: perspectives and social determinants. Victoria, Australia: Oxford University Press, 2012.

43. Lopez WD, Krueger PM, Walters ST. High-risk drug use and sexual behaviors among out-of-treatment drug users: an aging and life course perspective. Addict Behav 2010;35:432-7.

44. Dunbar T, Carson B, Chenhall RD, Bailie R, eds. Social determinants of Indigenous health. Sydney: Allen \& Unwin, 2007.

45. Walker R, Robinson M, Adermann J, et al. Chapter 22. Working with behavioural and emotional problems in young people. In: Dudgeon $\mathrm{P}$, Milroy $\mathrm{H}$, Walker R, eds. Working together: Aboriginal and Torres Strait Islander mental health and wellbeing principles and practice. Canberra: Commonwealth of Australia, 2014:383-98.

46. Walter M, Saggers S. Poverty and social class. In: Dunbar T, Carson $\mathrm{B}$, Chenhall RD, Bailie R, eds. Social determinants of Indigenous health. Sydney: Allen \& Unwin, 2007:87-108.

47. Atkinson J. Trauma trails, recreating song lines: the transgenerational effects of trauma in Indigenous Australia. Melbourne: Spinifex Press, 2002.

48. Zubrick SR, Silburn SR, Lawrence DM, et al. The Western Australian Aboriginal child health survey: the social and emotional wellbeing of Aboriginal children and young people. Perth: Curtin University of Technology and Telethon Institute for Child Health Research, 2005

49. Zubrick SR, Dudgeon P, Gee G, et al. Social determinants of Aboriginal and Torres Strait Islander social and emotional wellbeing. In: Purdie N, Dudgeon P, Walker R, eds. Working together: Aboriginal and Torres Strait Islander mental health and wellbeing principles and practice. Canberra: Department of Health and Ageing, 2010:75-90.

50. Australian Institute of Health and Welfare (AlHW). Child protection Australia: 2013-14. Child Welfare series no61Cat no CWS 52. Canberra: Australian Institute of Health and Welfare (AlHW), 2015.

51. Delfabbro $\mathrm{P}$, Hirte $\mathrm{C}$, Rogers $\mathrm{N}$, et al. The over-representation of Aboriginal and Torres Strait Islander in the South Australian child system: a longitudinal analysis. Child Youth Serv Rev 2010;32:1418-25.

52. Paradies YC, Cunningham J. The DRUID study: racism and self-assessed health status in an indigenous population. BMC Public Health 2012:12:131.

53. Priest $\mathrm{N}$, Paradies $\mathrm{Y}$, Stewart $\mathrm{P}$, et al. Racism and health among urban Aboriginal young people. BMC Public Health 2011;11:568-77.

54. Cunneen $C$. Colonial processes, indigenous peoples, and criminal justice systems. In: Bucerius S, Tonry M, eds. Oxford handbook of ethnicity, crime and immigration. New York: Oxford University Press, 2014:386-407.

55. Cunneen C. The Effects of Colonial Policy: Genocide, Racism and Aboriginal People in Australia. In: Prum M, Deschamps B, Barbier M-C, eds. Racial, Ethnic, and Homophobic Violence: Killing in the Name of Otherness. London: Routledge-Cavendish, 2006:17-30

56. Baldry E, Cunneen C. Imprisoned Indigenous women and the shadow of colonial patriarchy. Aust N Z J Criminol 2014;47: 276-98.

57. Australian Institute of Health and Welfare. Children and young people at risk of social exclusion: links between homelessness, child protection and juvenile justice. Data linkage series no. 13 Cat. no. CSI 13. Canberra: AlHW, 2012

58. Baldry E, Dowse L, Clarence M. People with mental health and cognitive disabilities: pathways into prison. Outlaws to Inclusion Conference; Sydney, Australia: UNSW FASS, 2012.

59. Alterman Al, Langenbucher J, Morrison RL. State-level treatment outcome studies using administrative databases. Eval Rev 2001;25:162-83. 
60. Hser YI, Evans E. Cross-system data linkage for treatment outcome evaluation: lessons learned from the California Treatment Outcome Project. Eval Program Plann 2008;31:125-35.

61. Hser YI, Teruya C, Evans EA, et al. Treating drug-abusing offenders: initial findings from a five-county study on the impact of California's Proposition 36 on the treatment system and patient outcomes. Eval Rev 2003;27:479-505.

62. Larm P, Hodgins S, Tengström A, et al. Trajectories of resilience over 25 years of individuals who as adolescents consulted for substance misuse and a matched comparison group. Addiction 2010;105:1216-25

63. National Health Service (NHS). A long-term outcome study of the outcomes of drug users leaving treatment. London, UK: National Treatment Agency for Substance Misuse, 2010.

64. Australian Institute of Health and Welfare. Juvenile detention population in Australia. Canberra, Australia: Australian Institute of Health and Welfare, 2012.

65. Brame R, Mazerolle P, Piquero AR. Criminal career progression among serious youthful offenders in Australia. J Crim Justice 2010;38:340-7.

66. Baldry E, Dowse L. Compounding mental and cognitive disability and disadvantage: police as care managers. In: Chappell D, ed. Policing and the mentally ill: international perspectives. Boca Raton, USA: CRC Press, Taylor and Francis Group, 2013:219-34

67. Apel R, Sweeten G. Propensity score matching in criminology and criminal justice. In: Piquero AR, Weisburd D, eds. Handbook of quantitative criminology. New York: Springer, 2010:543-62.

68. National Institute for Health and Clinical Excellence (NICE). Assessing cost impact: methods guide. London, UK: NICE, 2011.

69. Craig D, Rice S. CRD Report 6: NHS economic evaluation database handbook. New York, UK: Centre for Reviews and Dissemination, 2007.

70. Gossop M, Darke S, Griffiths P, et al. The Severity of Dependence Scale (SDS): psychometric properties of the SDS in English and Australian samples of heroin, cocaine and amphetamine users. Addiction 1995;90:607-14.

71. Dennis ML, Rouke KM, Caddell JM. Global appraisal of individual needs: administration manual. (NIDA Grant No. R01-Da07864). Research Triangle Park, NC: Research Triangle Institute, 1993.

72. Darke S, Ward J, Hall W, et al. The Opiate Treatment Index (OTI) Researcher's Manual. National Drug and Alcohol Research Centre Technical Report Number 11. Sydney: National Drug and Alcohol Research Centre, 1991.

73. Darke S, Hall W, Wodak A, et al. Development and validation of a multi-dimensional instrument for assessing outcome of treatment among opiate users: the Opiate Treatment Index. Br J Addict 1992;87:733-42.

74. Herdman M, Gudex C, Lloyd A, et al. Development and preliminary testing of the new five-level version of EQ-5D (EQ-5D-5L). Qual Life Res 2011;20:1727-36.

75. Pink B. Australian and New Zealand Standard Offence Classification (ANZSOC). Canberra: Australian Bureau of Statistics, 2011.

76. Lawrinson P, Copeland J, Indig D. Development and validation of a brief instrument for routine outcome monitoring in opioid maintenance pharmacotherapy services: The brief treatment outcome measure (BTOM). Drug Alcohol Depend 2005;80:125-33.

77. Dennis ML, Funk R, Godley SH, et al. Cross-validation of the alcohol and cannabis use measures in the Global Appraisal of Individual
Needs (GAIN) and Timeline Followback (TLFB; Form 90) among adolescents in substance abuse treatment. Addiction 2004;99:120-8.

78. Lawrinson P, Copeland J, Indig D. The brief treatment outcome measure: opioid maintenance pharmacotherapy (BTOM) manual. National Drug and Alcohol Research Centre (NDARC) Technical Report No. 156. Sydney: National Drug and Alcohol Research Centre, UNSW, 2003

79. Byles J, Byrne C, Boyle MH, et al. Ontario Child Health Study: reliability and validity of the general functioning subscale of the McMaster family assessment device. Fam Process 1988;27: 97-104.

80. Epstein NB, Baldwin LM, Bishop DS. The McMaster family assessment device. J Marital Fam Ther 1983;9:171-80.

81. Bell J, Shanahan $M$, Mutch $C$, et al. A randomised trial of effectiveness and cost effectiveness of observed versus unobserved administration of buprenorphine-naloxone for heroin dependence. Addiction 2007;102:1899-907.

82. Shanahan M, Havard A, Teesson M, et al. Patterns and costs of treatment for heroin dependence over 12 months: findings from the Australian Treatment Outcome Study. Aust N Z J Public Health 2006;30:305-11.

83. Shearer J, Shanahan M, Darke S, et al. A cost-effectiveness analysis of modafinil therapy for psychostimulant dependence. Drug Alcohol Rev 2010;29:235-42.

84. Howard J, Arcuri A. Predictors of retention, and client perceptions of treatment satisfaction and outcomes, among young people presenting to residential drug and alcohol treatment with alcohol as a primary or secondary substance of concern. Australia: Ted Noffs Foundation, 2005

85. Braun V, Clarke V. Using thematic analysis in psychology. Qual Res Psychol 2006;3:77-101.

86. Nathan S, Kemp L, Bunde-Birouste A, et al. "We wouldn't of made friends if we didn't come to Football United": the impacts of a football program on young people's peer, prosocial and cross-cultural relationships. BMC Public Health 2013;13:399.

87. May KA. On interviewing. Interview techniques in qualitative research: concerns and challenges. In: Morse JM, ed. Qualitative nursing research: a contemporary dialogue. CA: Sage Publications, 1991:187-201.

88. Bazeley P, Kemp L. Mosaics, triangles, and DNA: metaphors for integrated analysis in mixed methods research. $J$ Mixed Methods Res 2012;6:55-72.

89. Ezzy D. Qualitative analysis: practice and innovations. Australia: Allen \& Unwin, 2002

90. Hunter D, Pierscionek BK. Children, Gillick competency and consent for involvement in research. J Med Ethics 2007;33:659-62.

91. National Health and Medical Research Council (NHMRC). Keeping research on track: a guide for Aboriginal and Torres Strait Islander peoples about health research ethics. Canberra: Commonwealth of Australia, 2005

92. National Health and Medical Research Council (NHMRC). Values and ethics: guidelines for ethical conduct in Aboriginal and Torres Strait Islander health research. Canberra: Commonwealth of Australia, 2003.

93. McNelll F, Farall S, Lightower C, et al. How and why people stop offending: discovering desistance. UK: Institute for Research and Innovation in Social Services, 2012. 